\author{
I.I. Gab, T.V. Stetsyuk, B.D. Kostyuk, D.B. Shakhnin ${ }^{1}$
}

\title{
Kinetics of Dispersion During Annealing in Vacuum of Thin Double Nickel-Silver Films Deposited onto Oxide Materials
}

\author{
Frantsevich Institute for Materials Science Problems of NAS of Ukraine, Kyiv 03142, e-mail: gab@ipms.kiev.ua \\ ${ }^{I}$ University "Ukraine", Kyiv 03115, Ukraine, e-mail; shakhnin@ukr.net
}

\begin{abstract}
The kinetics of dispersion of thin nickel-silver films deposited onto alumina and zirconia ceramics and annealed in vacuum at temperatures up to $1000{ }^{\circ} \mathrm{C}$ with different exposition times at each temperature (from 5 up to $20 \mathrm{~min}$ ) was studied. The double films consisted of two layers: the first metallization layer was $150 \mathrm{~nm}$ nickel nanofilm deposited onto the oxide surface, and the second silver layer $1.5 \mu \mathrm{m}$ thick deposited over the first one as a solder was used for joining of metallized oxide samples. It was found that these films remain rather dense during short-term heating up to $900{ }^{\circ} \mathrm{C}$; and, after annealing at $950{ }^{\circ} \mathrm{C}$ and $1000{ }^{\circ} \mathrm{C}$, they decompose immediately into individual droplets covering more than half the area of the ceramic substrates. The kinetic curves for the dispersion of these films were plotted.
\end{abstract}

Key words: kinetics, dispersion, nickel-silver film, oxide materials.

Стаття поступила до редакиії 08.04.2019; прийнята до друку 15.06.2019.

\section{Introduction}

Joining ceramic materials with each other and with metals is carried out by two main methods:

1) brazing with molten metallic solders [1]-[3];

2) solid-phase pressure welding [4]-[6].

Since ceramic materials, particularly oxide ones, are usually poorly wetted by molten metals, metal coatings are often used applied in various ways (electron beam sputtering, magnetron sputtering, chemical deposition etc.). Adhesive-active metals such as titanium, chromium, niobium and others are the most commonly used to make such coatings. Then, thus metallized ceramic parts are brazed in vacuum or an inert medium (argon, helium etc.) by molten metallic solders on the basis of tin, silver, copper, nickel etc. In this case, the thickness of the solder seam is from $50-100 \mu \mathrm{m}$ up to several millimeters. Sometimes, multilayer metal coatings are used, but the thickness of the layers and brazed seams remains high [7]-[9].

At the same time, there is information that the reduction in the thickness of the brazed seam leads to a significant increase in the strength of the brazed joint [10]-[12]. Obtaining brazed or welded joints of metallized ceramics is possible through reducing the thickness of both the metallization coating on the ceramics and the brazing layer by itself. This can be achieved if the soldering metal or alloy is also applied in the form of a rather thin film, the thickness of which does not exceed several $\mu \mathrm{m}$. In addition, a thin soldering seam allows you to obtain precision welded or brazed ceramic and ceramic-metal units which can be used in microelectronics, radio engineering, microwave engineering etc.

This objective can be achieved by application onto the ceramic surfaces of double metal films, one of which is 100-200 nm thick and consists of an adhesion-active metal such as $\mathrm{Ti}, \mathrm{Cr}$ etc., and the other is slightly thicker $(2-3 \mu \mathrm{m})$ and serves as a solder, e.g. $\mathrm{Cu}, \mathrm{Ag}$ etc., which will ensure joining of metallized ceramic materials during brazing or welding with fine $(2-4 \mu \mathrm{m}$ thick) solder seam.

In literature there is information on the use of twoand multilayer metal coatings in production of aircrafts, in structures to be implanted into the human body, in devices for flat displays, light-emitting devices and solar panels, in friction units, as sensitive elements of strain gauges, in erosion-resistant coatings of blades for engines of various purposes, as coatings for cutting tools and machine parts [13]-[18].

The structure of such two- or multiphase coatings, determination of the optimal ratio of the thickness of each layer, processes of interaction at the phases interface, including the ceramic phase, is also an important area of research.

The study of two-layer nickel-silver coatings (films) on oxide materials during annealing in vacuum and the creation of brazed and welded oxide ceramics joints based on them with super-thin brazed seam, the thickness of which does not exceed $5 \mu \mathrm{m}$, is the main task of the present work. 


\section{Materials and Experimental Procedure}

In this paper an electron-beam method for sputtering of metal nanofilms was used.

The thickness of the deposited nanofilms was measured by two methods:

1) the metal of the given weight (calculated for films of the required thickness) is completely evaporated, then

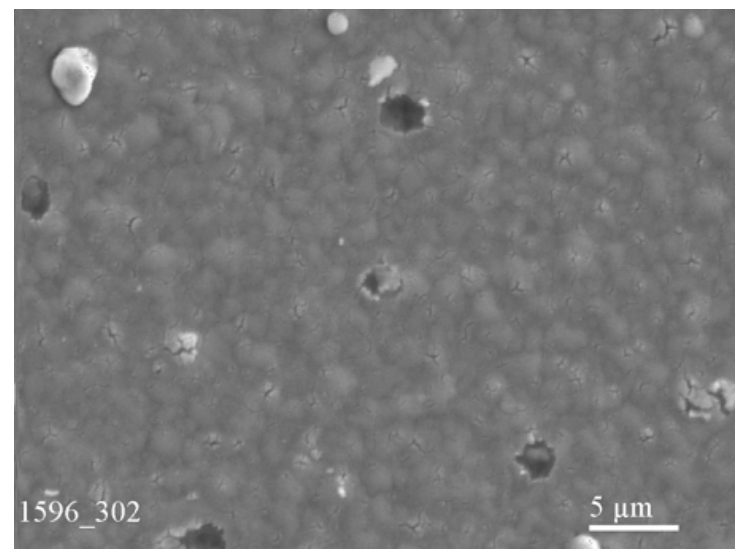

$\mathbf{a}$

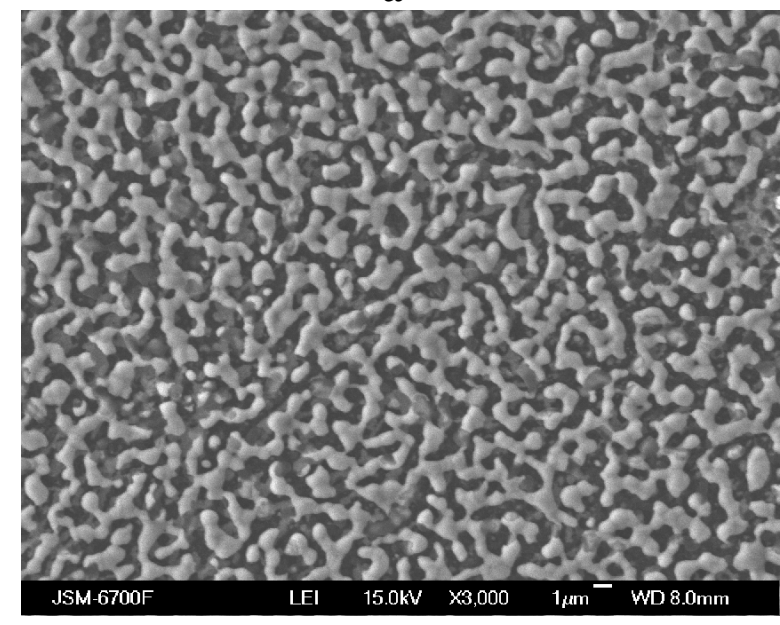

b

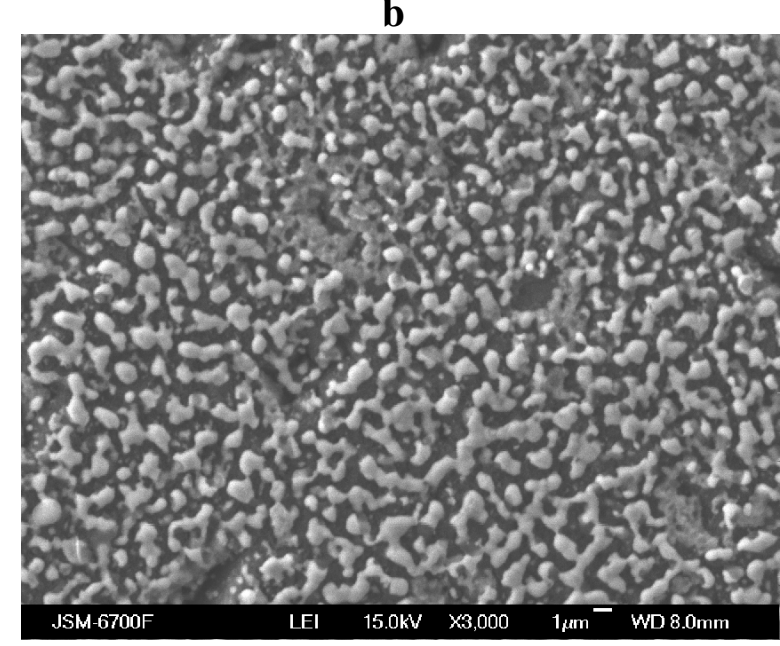

c

Fig. 1. SEM image nickel-silver double-film onto alumina ceramics which was annealed in vacuum, x3000: a $-900{ }^{\circ} \mathrm{C}, 5 \mathrm{~min} ; \mathrm{b}-900{ }^{\circ} \mathrm{C}, 20 \mathrm{~min}$; c $950{ }^{\circ} \mathrm{C}, 20 \mathrm{~min}$. the thickness of the film can be easily calculated according to the law of Lambert [19], [20];

2) with the help of a special quartz sensor located in the vacuum sputtering chamber near the sample on which the film is deposited.

Solid non-metallic substrates were made of alumina and zirconia ceramics as small thin plates $4 \times 3 \times 2 \mathrm{~mm}$ in size. One of the flat surfaces of each specimen was well polished to a roughness $\mathrm{R}_{\mathrm{z}}=0.03 \div 0.05 \mu \mathrm{m}$. After polishing, all specimens were thoroughly defatted and burned in air at $1100{ }^{\circ} \mathrm{C}$ for one hour.

As a metal deposited directly onto non-metallic surfaces, nickel was used. Metallized samples were then coated by silver films serving as a solder when joining the samples.

The quality of all applied nanofilms was controlled using a XJL-17 metallographic microscope.

The specimens with deposited onto them metal films were annealed in a vacuum chamber for various periods of time (from 5 up to $20 \mathrm{~min}$ ) and at different temperatures (from $900^{\circ} \mathrm{C}$ up to $1000^{\circ} \mathrm{C}$ ) in the vacuum not less than $2 \times 10^{-3} \mathrm{~Pa}$.

Annealed specimens were investigated using scanning electron microscopes JSM-6700 F and Superprobe 733 with microphotographs storing. Using these microphotographs, the areas of metal islets on the surface of non-metallic samples were determined by the planimetric method, i.e. by weighing the elements of the metallized surfaces of samples carved out from the paper microphotograph copy [11]. The experimental data obtained were processed in the form of graphs showing the dependence of the surface area of the samples covered with metal nanofilms on the annealing parameters (temperature, time).

\section{Results and Discussion}

Annealing of a nickel-silver double-film at $900{ }^{\circ} \mathrm{C}$ slightly violated the integrity of the initial film on alumina ceramics surface after a five-minute exposition

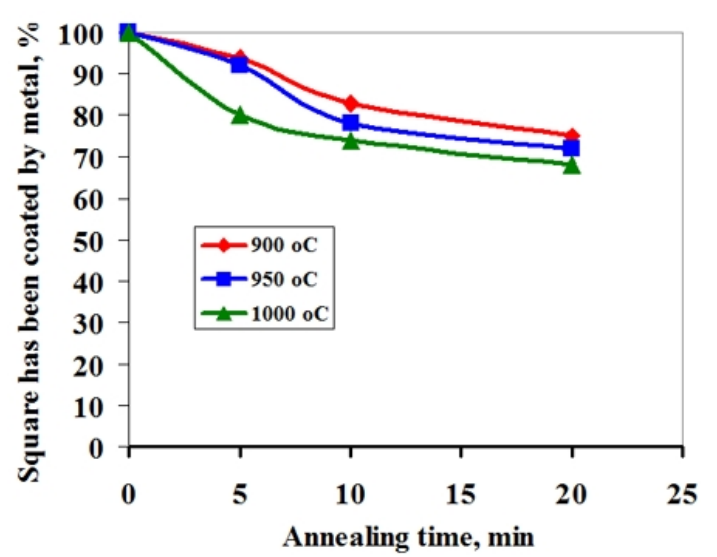

Fig. 2. Alumina ceramics area covered by nickelsilver double-film dependence on annealing time at various temperatures $\left(900-1000{ }^{\circ} \mathrm{C}\right)$. 


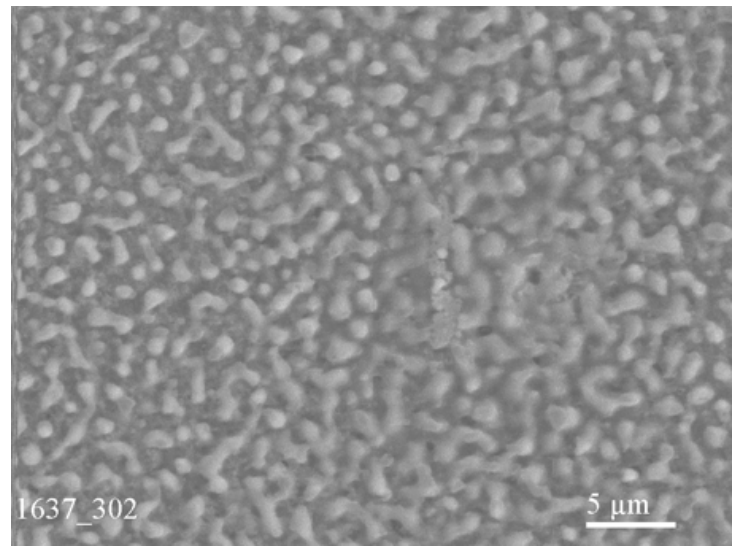

$\mathbf{a}$

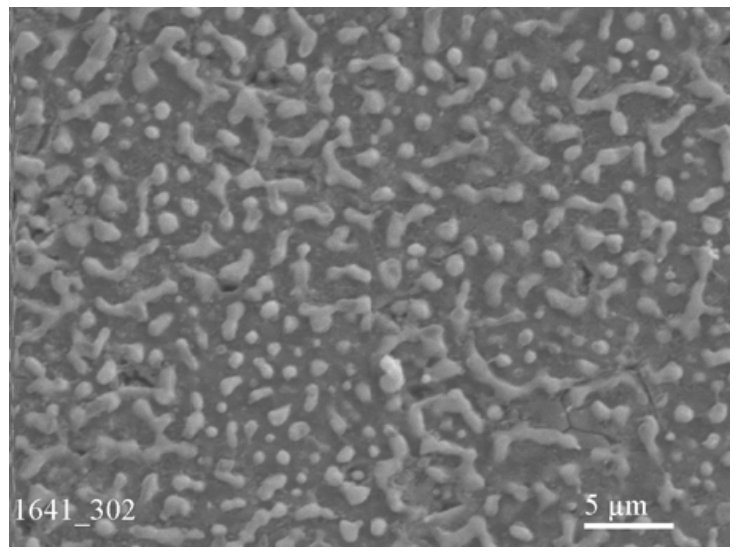

$\mathbf{b}$

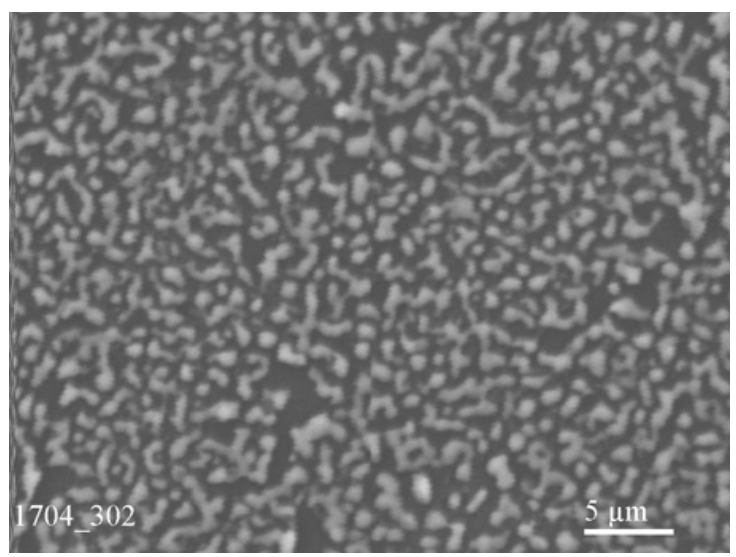

c

Fig. 3. SEM image nickel-silver double-film onto alumina ceramics which was annealed at $1000{ }^{\circ} \mathrm{C}$ in vacuum, $\mathrm{x} 3000$ : $\mathrm{a}-5 \mathrm{~min}$; $\mathrm{b}-10 \mathrm{~min}$; $\mathrm{c}-20 \mathrm{~min}$.

(Fig. 1,a; 2). A ten-minute annealing significantly intensified the process of decomposition of the film, and twenty-minute exposition at $900{ }^{\circ} \mathrm{C}$ leads to the disintegration and dispersion of silver film coating about $75 \%$ of the sample surface covered with nickel (Fig. 1, $\mathrm{b} ; 2)$. The increase of the annealing temperature up to $950{ }^{\circ} \mathrm{C}$ slightly intensified the process of the film dispersion compared with annealing at $900^{\circ} \mathrm{C}$; namely, after a five-minute exposition, the disruption area was about $10 \%$ of the whole surface area of the sample, after ten minutes - $20 \%$, and after twenty minutes - $25 \%$ (Fig. 1, c; 2). All these studies make it possible to use a double film for pressure welding of metallized ceramic specimens at temperatures of $900 \div 950{ }^{\circ} \mathrm{C}$, i.e. at temperature lower than the melting point of silver $\left(962{ }^{\circ} \mathrm{C}\right)$.

Annealing at $1000{ }^{\circ} \mathrm{C}$ led immediately to the silver layer melting and decomposition into separate drops after five minutes of exposition (Fig. 3, a; 2), covering about $80 \%$ of the whole surface of the nickel metallization

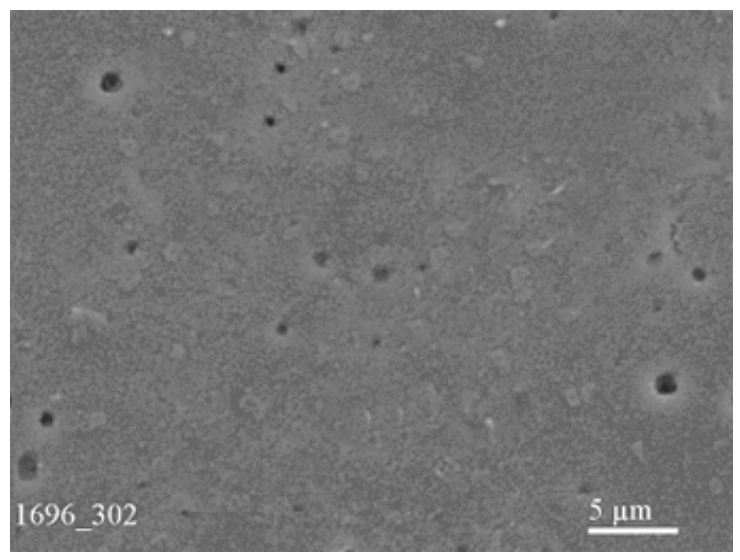

$\mathbf{a}$
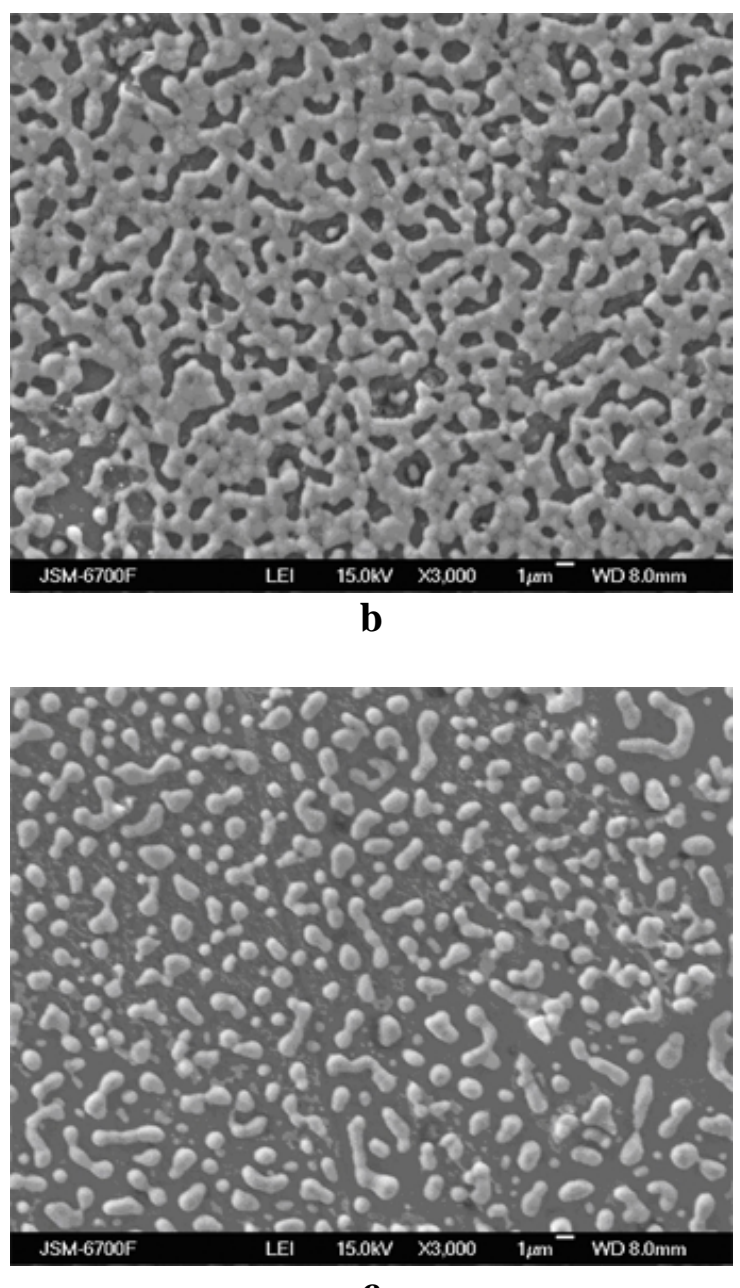

c

Fig. 4. SEM image nickel-silver double-film onto zirconia ceramics which was annealed in vacuum, $\mathrm{x} 3000$ : a $-900{ }^{\circ} \mathrm{C}, 5 \mathrm{~min}$; $\mathrm{b}-900^{\circ} \mathrm{C}, 20 \mathrm{~min}$; c $950{ }^{\circ} \mathrm{C}, 20 \mathrm{~min}$. 


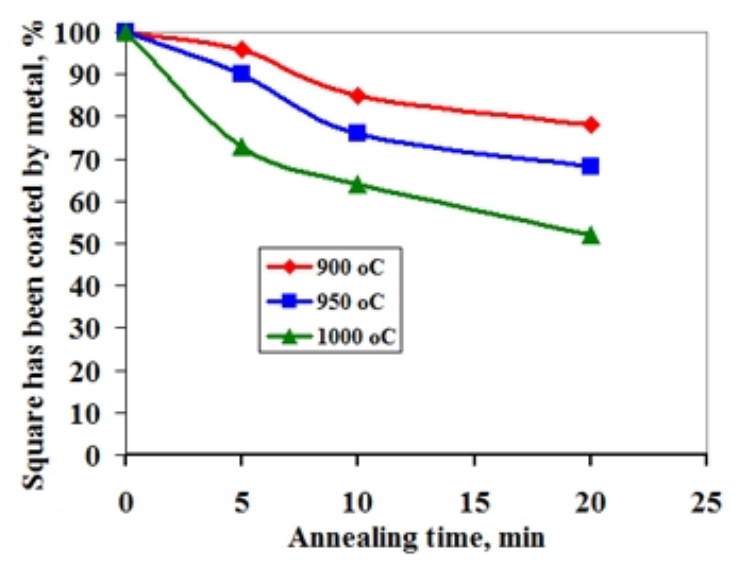

Fig. 5. Zirconia ceramics area covered by titanium film dependence on annealing time at various temperatures $\left(900-1000{ }^{\circ} \mathrm{C}\right)$.

coating on the ceramic sample surface. With further annealing during ten minutes, the dispersion of the film increased (Fig. 3, b; 2); and after twenty minutes the dispersed silver film covered about $70 \%$ of the whole surface of the nickel metallization coating on the ceramic specimen surface (Fig. 3, c; 2).

Thus, such double Ni-Ag film can be used to join by brazing the metallized alumina ceramic samples, but with a small load up to $1 \mathrm{MPa}$.

The behavior of the double nickel-silver film on zirconia ceramics surface was almost completely identical to its behavior on alumina one, i.e. five-minute annealing of the continuous film at $900{ }^{\circ} \mathrm{C}$ did not lead to significant changes in the film morphology (Fig. 4, a; 5). With a ten-minute exposition, the film began to disperse and after twenty-minute annealing the disintegration of the film intensified (Fig. 4, b; 5). The processes of dispersion of the film intensified somewhat as a result of annealing at $950{ }^{\circ} \mathrm{C}$; but even after twenty minute annealing, the silver film still covered about $70 \%$ of the whole surface of the metallized ceramic substrate (Fig. 4, c; 5). Thus, this film is also suitable for the formation of zirconia ceramics joints by pressure welding.

After annealing at $1000{ }^{\circ} \mathrm{C}$ the silver layer, as in case of alumina ceramics, melts and disperses already after five (Fig. 6, a; 5) and ten minutes of annealing (Fig. 6, b; 5); and after twenty-minute exposition rounded silver droplets cover about $50 \%$ of whole surface coated by nickel (Fig. 6, c; 5). So, double nickel-silver films can be used to join zirconia samples by pressure welding at $950{ }^{\circ} \mathrm{C}$ with the process time limitation up to five minutes.

Brazing of metallized zirconia ceramic samples with molten silver at $1000{ }^{\circ} \mathrm{C}$ with a small load (up to $1 \mathrm{MPa}$ ) can be recommended only in the short-term process (up to five minutes).

\section{Conclusions}

Studies of the behavior of double nickel-silver thin films deposited onto samples of alumina and zirconia ceramics during annealing found that such films

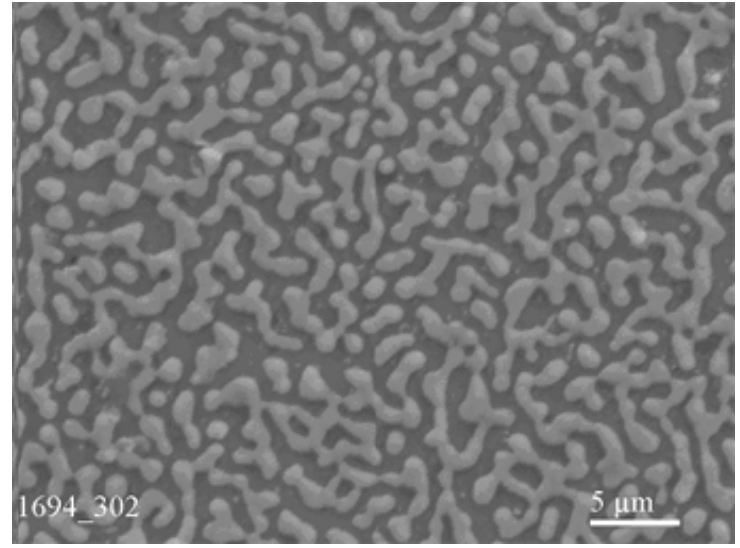

$\mathbf{a}$

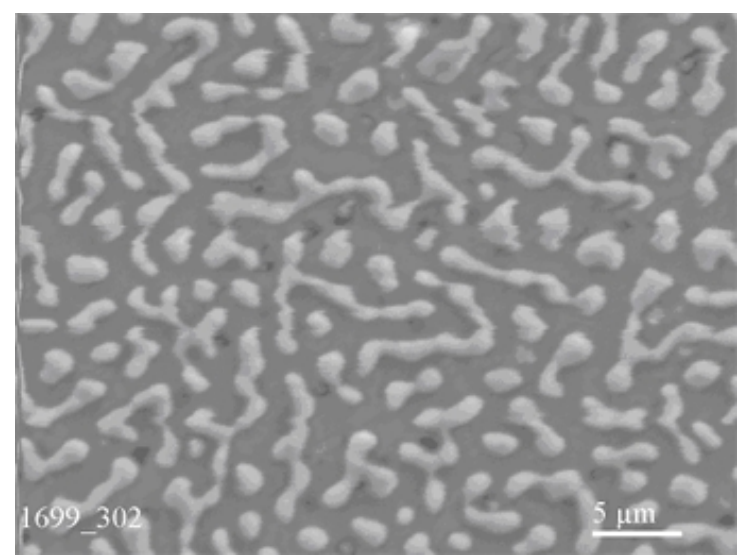

b

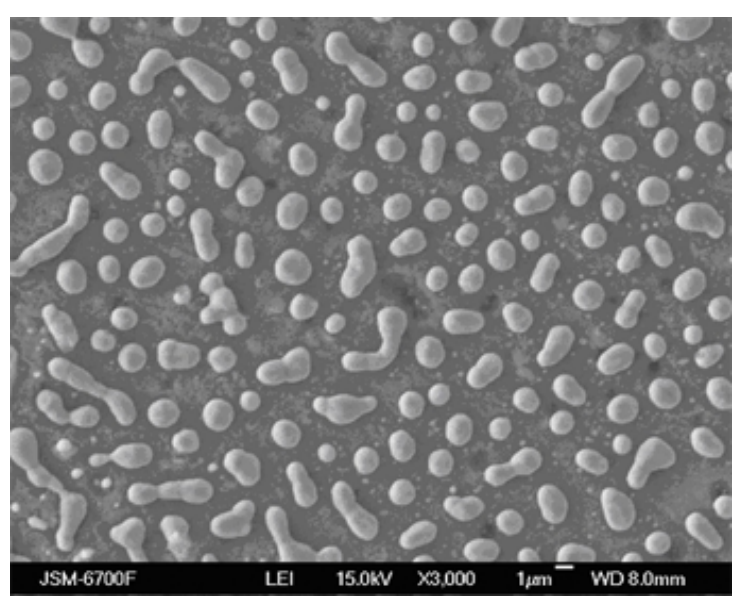

c

Fig. 6. SEM image nickel-silver double-film onto zirconia ceramics which was annealed at $1000{ }^{\circ} \mathrm{C}$ in vacuum, $x 3000$ : $a-5$ min; $b-10 \min ; c-20 \min$.

remained sufficiently continuous when heated up to $900^{\circ} \mathrm{C}$.

With further increase of the annealing temperature up to $950^{\circ} \mathrm{C}$ the film begins to disperse intensely into separate fragments covering almost $70 \%$ of the whole nickel-metallized ceramic substrate.

Annealing at $1000^{\circ} \mathrm{C}$ leads to an instant melting of a silver film that splits into individual droplets covering almost $70 \%$ of the whole nickel-metallized surface of the alumina ceramics substrate and about $50 \%$ of the 
whole surface of the zirconia ceramics substrate.

The pattern of the decomposition of the film on both oxide ceramics is almost the same; on the zirconia ceramics substrate the film decomposes a little more, as a result of which its residues are cover a slightly smaller part of the whole substrate surface compared to alumina ceramics.

The kinetic curves of dispersion during annealing of double nickel-silver films on alumina and zirconia ceramics were plotted, using which it is possible to determine the basic technological parameters (temperature and exposition time at this temperature) of the processes of joining of ceramic materials by brazing or pressure welding. According to these plots, it can be concluded that the most suitable method for joining the samples metallized with studied films is pressure welding allowing the joining process to be carried out at $900 \div$ $930^{\circ} \mathrm{C}$ when the film is still sufficiently continuous.

The joining of metallized samples of alumina by brazing at $950 \div 1000{ }^{\circ} \mathrm{C}$, when the silver layer of the film is melted, is possible with a small load (up to $1 \mathrm{MPa}$ ), but the process must be substantially limited in time by not more than five - seven minutes, when the fragments of the molten film covering even more than $80 \%$ of the whole substrate surface area, and the brazing of metallized zirconia ceramics at these temperatures is not possible since the film fragments cover a small part of the whole sample surface $(\sim 50 \%)$.

$\boldsymbol{G a b}$ I.I. - candidate of science (tech.), senior research fellow, leading researcher;

Stetsyuk T.V. - researcher;

Kostyuk B.D. - candidate of chemical sciences, senior researcher fellow,

Shakhnin D.B. - candidate of chemical sciences, associate professor.

[1] M. A. Rubashev, G. I. Berdov, V. N. Gavrilov, M. L. Lyubimov et all, Termostoykiye dielektriki i ikh spai s metallami v novoy tekhnike (Atomizdat, Moskva, 1980).

[2] Yu. V. Naidich, Kontaktnyye yavleniya v metallicheskikh rasplavakh (Naukova dumka, Kiev, 1972).

[3] N. F. Lashko, S. V. Lashko, Payka metallov (Mashinostroyeniye, Moskva, 1967).

[4] N. F. Kazakov, Diffuzionnaya svarka materialov (Mashinostroyeniye, Moskva, 1976).

[5] V. A. Bachin, Teoriya, tekhnologiya i oborudovaniye diffuzionnoy svarki (Mashinostroyeniye, Moskva, 1991).

[6] I. I. Metelkin, M. A. Pavlova, N. V. Pozdeyeva, Svarka keramiki s metallami (Metallurgiya, Moskva, 1977).

[7] V. R. Yevdokimov, S. L. Kashtanov, L. N. Lado, S. N. Shubin, Svarochnoye proizvodstvo 8, 2 (1995).

[8] M. Sirakane, M. Nakakhasi, T. Yamadzaki, Zayavka 60-239373, Yaponiya Zayavl. 15.05.84. Opubl. 28.11.85.

[9] M. Namura, Y. Ito, K. Kaneya, Zayavka № 380163 Yaponiya. Zayavl. 21.08.89. Opubl. 04.04.91.

[10] Yu. Naidich, Industrial Ceramics 19 (3), 162 (1999).

[11] Yu. V. Naidych, Y. Y. Gab, B. D. Kostyuk, T. V. Stetsyuk, D. Y. Kurkova, S. V. Dukarov, Dopovidi Natsionalnoi akademii nauk Ukrainy 35, 97 (2007).

[12] Yu. V. Naidych, Y. Y. Gab, B. D. Kostyuk, T. V. Stetsyuk, D. Y. Kurkova, S. V. Dukarov, Tekhnika mashinostroyeniya 1, 28 (2006).

[13] V. M. Yakovich V. M. Komarovskaya, Inzhenerno-pedagogicheskoye obrazovaniye v XXI veke: materialy XII Respublikanskoy nauchno-prakticheskoy konferentsii molodykh uchenykh i studentov BNTU (BNTU, Minsk, 2016), p. 215.

[14] A. A. Andreyev, G. I. Kostyuk, N. A. Minayev, Aviatsionno-kosmicheskaya tekhnika i tekhnologiya 89 (2), 28 (2012).

[15] S. V. Zaytsev, Yu. V. Gerasimenko, M. V. Lobanov, A. M. Khoviv, Kondensirovannyye sredy i mezhfaznyye granitsy 16 (2), 153 (2014).

[16] T. A. Lobanova, A. O. Volkhonskiy, I. V. Blinkov, Innovatika i ekspertiza 10 (1), 76 (2013).

[17] D. V. Velikodnyy, C. I. Protsenko, I. Ye. Protsenko, FIP 6 (1-2), 37 (2008).

[18] M. Naveed, A. Obrosov, S. Weib, Hindawi Publishing Corporation Conference Papers in Science Volum, ID 873543 (2015); http://dx.doi.org/10.1155/2015/873543.

[19] S. Metfessel, Tonkie plenki, ih izgotovlenie i izmerenie (Gosenergoizdat, Moskva-Leningrad, 1963).

[20] G. Khaas, R. E. Tun, Fizika tonkikh plenok (Mir, Moskva, 1968). 


\title{
I.I. Габ, Т.В. Стецюк, Б.Д. Костюк, Д.Б. Шахнін ${ }^{1}$
}

\section{Кінетика диспергування при відпалі у вакуумі тонких подвійних нікелево-срібних плівок, нанесених на оксидні матеріали}

\author{
Інститут проблем матеріалознавства ім. І. М. Францевича НАН України, м. Киӥв, 03142, \\ Украӥна, е-таil: gab@ipms.kiev.ua \\ ${ }^{1}$ Університет „Україна”, м. Київ, 03115, Україна
}

\begin{abstract}
Досліджена кінетика диспергування тонких нікелево-срібних плівок, що нанесені на алюмоокидну та диоксидноцирконієву кераміки та відпалені у вакуумі при температурах до $1000{ }^{\circ} \mathrm{C}$ при різних термінах витримки при кожній температурі (від 5 до 20 хв). Подвійні плівки складалися 3 двох шарів: перший металізований шар являв собою нікелеву наноплівку завтовшки 150 нм, нанесену на поверхню оксиду, а на неї був нанесений срібний шар завтовшки 1,5 мкм, який мав слугувати в якості припою при з'єднанні між собою металізованих керамічних зразків. Виявлено, що ці плівки залишаються досить щільними при нетривалому нагріванні їх до $900{ }^{\circ} \mathrm{C}$, а після відпалу при $950{ }^{\circ} \mathrm{C}$ та $1000{ }^{\circ} \mathrm{C}$ розпадаються відразу на окремі краплі, які вкривають більш ніж половину площі керамічних підкладок. Побудовані кінетичні криві диспергування даних плівок.

Ключові слова: кінетика, диспергування, нікелево-срібна плівка, оксидні матеріали.
\end{abstract}

